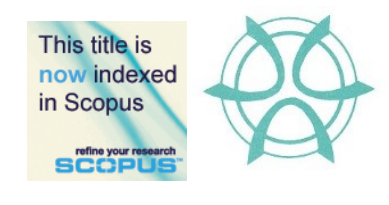

PLANNING MALAYSIA:

Journal of the Malaysian Institute of Planners

VOLUME 19 ISSUE 4 (2021), Page 173 - 184

\title{
AN IMPROVEMENT OF INTEGRATED GEOGRAPHICAL INFORMATION SYSTEM IN MANAGING SEWERAGE TREATMENT PLANT
}

\author{
Muhamad Zuraini Idris ${ }^{1}$, Robiah Suratman ${ }^{2}$, Salfarina Samsuddin ${ }^{3}$ \\ ${ }^{1,2,3}$ Faculty of Built Environment and Surveying \\ UNIVERSITI TEKNOLOGI MALAYSIA, MALAYSIA
}

\begin{abstract}
In Malaysia, the Geographical Information System (GIS) is widely used by various organizations in both government and private sectors because of its various capabilities. The rapid development process in the large city in Peninsular Malaysia and new area has caused an increasing number of the sewerage treatment plant (STP) maintained by Indah Water Konsortium Sdn Bhd (IWK) every year. Nowadays, with the big services areas and limited staffs the IWK had faced many issues related to the sewerage such as a public complaint on blockage, overflow and others. Thus, based on the powerful function of this GIS, the IWK also has used the GIS application known as Integrated Geographical Information System (IGIS) in their daily routine works. However, due to the weaknesses of this existing system, it cannot be optimally utilized in managing and maintaining the sewerage system more efficient. The main objective of this research focuses on analyzing user requirements to improve IGIS based on the current issues faced by them. The method used in this study is qualitative method using a face-to-face interview with IGIS users in getting any feedback from them on the existing data with an examining what is the main attribute data required. Then a content analysis was used to analyze it by updating all the data required and removing unnecessary data from the IGIS. As a result, the newly updated attribute data into IGIS will help the users to conduct proper planning in controlling the increasing number of STP every year and to manage the sewerage system more efficiently.
\end{abstract}

Keywords: Geographical Information System, Sewerage Treatment Plant, Decision Making Process, Facilities Management

\footnotetext{
${ }^{1}$ Land Administration and Development Postgraduate Student Email: zuraini4879@gmail.com
} 
Muhamad Zuraini Idris, Robiah Suratman, Salfarina Samsuddin

An Improvement of Integrated Geographical Information System in Managing Sewerage Treatment Plant

\section{INTRODUCTION}

Nowadays, there are many new development areas that had grown in the major cities in Malaysia because of the increasing number of demands in property especially the residential and commercial sector. The sewerage treatment plant (STP) facility is one of the important amenities that need to be provided by the developer in order to ensure well-being and comfort for the property buyers and that were also stated in related gazetted guidelines. Established on the $2^{\text {nd }}$ of April 1994, the Indah Water Konsortium Sdn Bhd (IWK) had been appointed by the Malaysia government to manage, operate and maintain a sewerage system nationwide. Before this sewerage company was established, the sewerage system was previously managed by a local authority (LA) in every district of state in Malaysia. IWK took over this service from the LA in the year 1994 as part of a concession agreement with the federal government that does not include the state of Kelantan, Sabah, Sarawak, Majlis Bandaraya Johor Bahru and Majlis Perbandaran Pasir Gudang (The Malaysia Reserve, March 28, 2019). The existence of the new development areas had caused an increasing number of the STP and public sewerage sewer line (SPPA) that needs to be maintained and operated by IWK every year. As of March 2021, the total number of STP's maintained by IWK is 11,857 in Peninsular Malaysia including 102 LAs with total length of sewer line of 20,623 kilometres (IWK, March 2021). Thus, this increasing number of STP's and sewer line shows that IWK needs to spend extra cost for their operation and maintenance works (Kumpulan Media Karangkraf, 2018). With the low tariff that had been charged to their customers, IWK is constantly seeing a loss in their profit since being established in the year 1994 (Berita Harian, 2012).

The recent advances in information technology (IT) have made the Geographical Information System (GIS) in this country to become the most popular application and it has been actively used by many government departments and agencies including the private sector, due to its various capabilities. The various capabilities of this GIS include its ability to store and manage data and information that helps the users in decision-making especially in planning and the development stage, which is also capable to act as a management platform (DeMers, 2005). Throughout the years, IWK has faced many issues such as in identifying the critical SPPA, an illegal connection from the industrial and commercial areas, the river pollution at the nearest STP, the squatter problem on the STP land, and amongst other issues. Therefore, in order to ensure the smooth process in their daily work, and to facilitate access to information needed, IWK had developed a GIS application known as Integrated Geographical Information System (IGIS). Currently, by using this IGIS, the users can view the location of STP and SPPA on the ground through their computer desktop in the office.

The aim of this paper is to look on how the improvement of existing IGIS can be used for the purpose of managing and controlling the increasing number of new STP. Besides that, it also to look into what is the effectiveness of this IGIS 
PLANNING MALAYSIA

Journal of the Malaysia Institute of Planners (2021)

improvements whether it can help the IWK to solve their current issues and problems.

\section{PROBLEM STATEMENT}

The GIS application had been used in IWK for more than 10 years and it is proven to help the Planning and Land Section (PLS) during the planning stage especially in controlling the increasing number of the STP every year. However, there are some weaknesses in this existing IGIS that needs to be improved from time to time because it cannot be optimally utilized in managing and maintaining the sewerage system. The main weakness of this existing IGIS is the lack of relevant information that need to be updated in the IGIS. The increasing number for STP has created many problems to IWK, particularly in the following departments or sections:

\section{Operation and Maintenance Department (OMD)}

The increasing number of STP and SPPA took over by IWK every year had seen the OMD faced a lot of problems in their daily work. Whilst covering such big area for maintenance and limited number of staffs, the operation and maintenance work for STP and SPPA is very difficult to be done properly. The major challenges in maintaining the SPPA faced by the OMD, are the issues of blockage and overflow. These two issues are the frequent complaints received by the OMD from the public. It can easily be caused by a mere act of an irresponsible person dumping a solid waste into a toilet bowl, which happens due to the lack of awareness among the public about sanitation. Other issues faced by OMD are conducting a maintenance work for all unused or rationalized STP. Based on the database for the month of March 2021, there are 732 STP sites that had been rationalized nationwide (IWK, March 2021). IWK had received a lot of complaints from the public for unused or rationalized STP such as odor and breeding of mosquitoes area. Based on a local news report in year 2018, complaints were made by 1,000 residents of Tman Seri Marina Phase 1 in Kuala Kedah on the daily stench smell coming from the fiveyear-old idle STP (Utusan Malaysia, December 11, 2018). The STP is very synonymous with IWK as the national sewerage company, though this former sewerage site was handed over to the Sewerage Services Department (JPP) officially on the $1^{\text {st }}$ of January 2016 for maintenance works that includes to demolish the structure, security and others. Indirectly, these issues has resulted in a bad reputation towards the IWK image for unused or rationalized STP due to poor maintenance.

\section{Planning and Land Section (PLS)}

Currently, the GIS unit under PLS faces the biggest challenge in updating related information on new STP and SPPA in IGIS. The main problem is significantly caused by outstanding received documentation from related Certifying Agency unit (CA). This causes the delay in updating and capturing the latest information, 
Muhamad Zuraini Idris, Robiah Suratman, Salfarina Samsuddin

An Improvement of Integrated Geographical Information System in Managing Sewerage Treatment Plant

especially in identifying the connection points between existing STP or SPPA and those in new development, into IGIS. Thus, the information stated in IGIS is not up to date. In current practice, the property developers will liaise with the GIS Executive (GE) and Asset Executive (AE) in procuring any related information on STP or SPPA before submitting the form of Planning Approval (PDC1) to CA for approval. For the example, any wrong information on STP that is provided to the property developers, it will cause to an overloaded issues that will also affect the operational works such as breakdown or failure of the mechanical equipment. Thus, the updated information for STP is crucial to avoid these problems from reoccurring in the future. This study has learnt that due to the poor updating conducts, few cases were reported on existing sewer line that was not updated into IGIS due to outstanding documentation, as well as feedbacks from property developers on cases that has on-site existing developments but were not updated in GIS.

As a non-profit company, PLS have taken many initiatives to reduce the increasing number of STP every year by advising the property developers to upgrade existing STP into new design PE or to connect new development to the nearest existing STP. One of the major challenges faced by Planning Engineer (EP) in giving their comment towards upgrading STP is that the information on sewerage land is not completely captured in IGIS. According to the MSIG guideline, to upgrade the old design PE of STP to a new design, it needs to follow the requirements of land area that had been stated. Currently, the IGIS only captures the location of the sewerage land. Thus, the integration of information and documentation such as Certified Plan (CP) into the IGIS and land database system is seen as crucial to facilitate access to sewerage land information.

\section{Customer, Billing and Collection Department (CBCD)}

$\mathrm{CBCD}$ is one of the departments in IWK that is in-charge of all matters related to customers, billings, and collection of payment of IWK bills. With an increasing number of STP took over by IWK every year, it means the collected amount will be increased. Currently, IWK sends their sewerage bill to the customers every six months and the minimum charge is RM2 per month for the low-cost housing. Unfortunately, the collection of payment for sewerage bills is very low, mainly as a result on the level of awareness among the public to pay their sewerage bills is very poor. $\mathrm{CBCD}$ had taken an initiative to overcome this issue by collaborating with PLS in identifying the unpaid customers using IGIS. This program led by PLS is called the 'Non-Revenue Customers (NRC)'. The unpaid customer list will be provided by CBCD based on their billing records and PLS need to recheck the existing information in IGIS such as the address of the premises. However, this initiative is not $100 \%$ successful because of the customer database in CBCD system is not tally with IGIS database due to an outstanding issue. Another objective of 
PLANNING MALAYSIA

Journal of the Malaysia Institute of Planners (2021)

this NRC is to focus on the customers who have received IWK services, but the information on these customers is not captured in the billing database.

\section{Finance Department (FD)}

An accretion number of STP sees the cost of operation and maintenance incurred by IWK increases every year. This increasing number of STP with the lower sewerage tariff charged to the customers, seeing too difficult for IWK to cover up the increasing cost of operation and maintenance every year. In present time, IWK charges a household at an average of RM8 per month for their sewerage services despite the actual operating cost incurred by IWK that is between RM18 to RM20 (MStar, October 17, 2016). In addition, the IWK also needs to incur the cost of refurbishment works of STP, the problematic STP such as a structural defect and others.

Thus, based on the problems faced by IWK, it is seen as an urge to improve the IGIS application process. However, before any improvements can be made, it is necessary to review and study this existing system in terms of its capabilities and existing data (Maguire and Bevan, 2002). It is also necessary to review the user requirements to ensure that the output can help the IGIS application to function more effectively, for the purpose of managing the STP and SPPA. This paper reports on the use of the user requirements analysis for the purpose of identifying data, it needs to be based on the roles and functions of each stakeholder involved in the PLS, OMD and CA, to ensure the maintenance and management of STP and SPPA to be more efficient.

\section{METHODOLOGY OF RESEARCH}

A requirement is defined as a statement that identifies a necessary attribute, capability, characteristic or quality of a system in order for it to have a value and utility to a user (Young RR, 2001, T. Yue et.al, 2010). A successful system and product begin with an understanding of the needs and requirements of the users (Maguire and Bevan, 2002). Thus, the benefits getting from a successful system can help the organization to increase its productivity, to improve the satisfaction of the users, a reduction in support and training costs, and to enhance work quality. 
Muhamad Zuraini Idris, Robiah Suratman, Salfarina Samsuddin

An Improvement of Integrated Geographical Information System in Managing Sewerage Treatment Plant

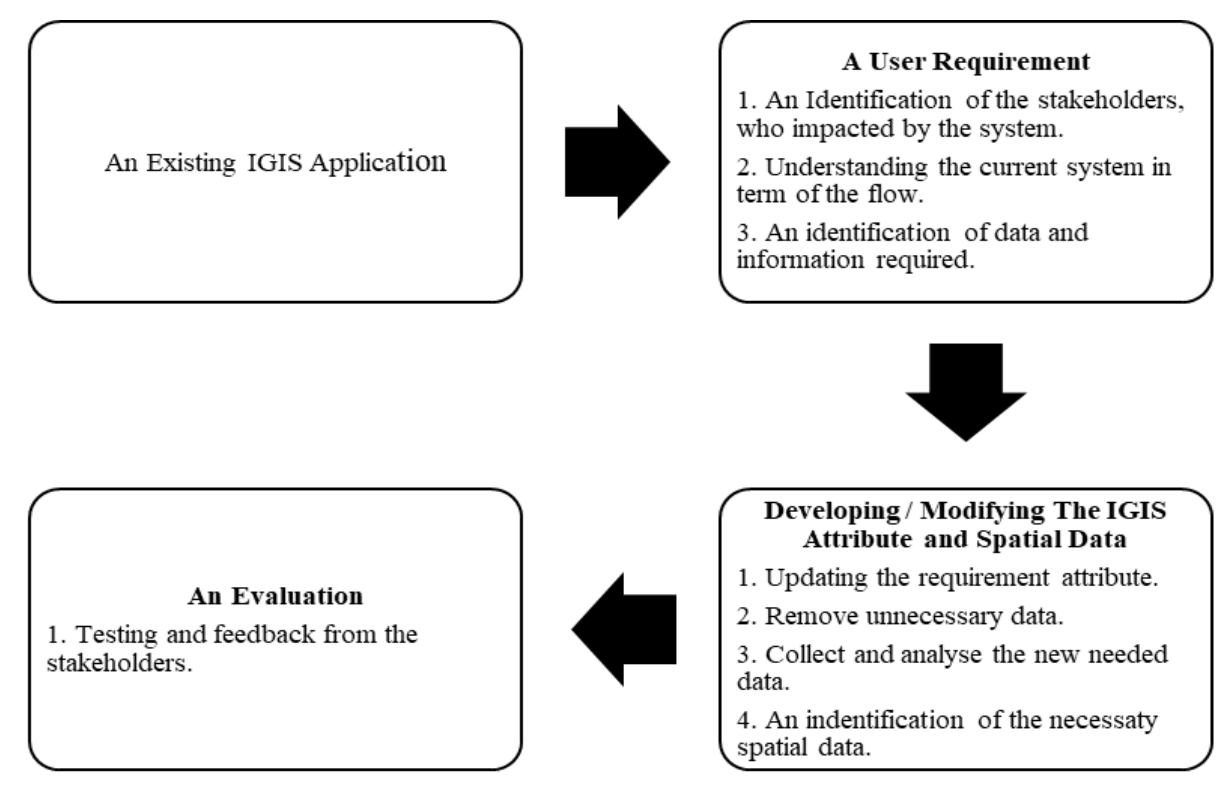

Figure 1: Study Approach

Figure 1 has shown the approach that has been used in this study. It starts with reviewing an existing IGIS of its spatial data, attribute data, functionality, and current capabilities. In terms of a user requirement, the IGIS users were identified, including their current scope related to this IGIS. Currently, there have 3 departments in IWK used this IGIS and it is PLS, OMD and CA. The qualitative method using a face-to-face interview with the IGIS users is the main method used in this study. Total number of IGIS respondents that had been selected and interview is 50 people and all of them is from these 3 departments. During a faceto-face interview, all the respondents were questioned in regards to determining the required or necessary spatial and attribute data that is related to their department (Henry and Charles, 2015). It is for the purpose of ascertaining the extent to which additional spatial and attribute data can be used by them in making a decision in managing and maintaining the STP and SPPA. The interview sessions were also able to collect feedbacks from IGIS respondents in regards to removing unnecessary spatial and attribute data from the IGIS. Then a content analysis has been used to analyze and collect the data needed into IGIS (Henry and Charles, 2015). It is done by updating the necessary spatial and attribute data by removing an unnecessary data from the IGIS. Finally, an additional data and functionality developed within the enhanced IGIS was demonstrated to the IGIS respondents from PLS, OMD and CA to obtain their feedback. 
PLANNING MALAYSIA

Journal of the Malaysia Institute of Planners (2021)

Table 1 shows the example of additional and removing attribute data for the enhanced IGIS and the results obtained are discussed in the next section of this paper.

Table 1: Summary of Improvement Attribute Data in New IGIS Application

\begin{tabular}{|c|c|c|c|c|}
\hline No. & Spatial Data & $\begin{array}{l}\text { Attribute Data } \\
\text { (Added) }\end{array}$ & $\begin{array}{c}\text { Attribute Data } \\
\text { (Removed) }\end{array}$ & Description \\
\hline \multirow[t]{3}{*}{1.} & $\begin{array}{l}\text { Sewerage Treatment } \\
\text { Plant (STP) }\end{array}$ & & Object ID & $\begin{array}{l}\text { Unnecessary } \\
\text { data }\end{array}$ \\
\hline & & & Category & $\begin{array}{l}\text { Unnecessary } \\
\text { data }\end{array}$ \\
\hline & & Street Name & & \\
\hline \multirow[t]{7}{*}{2.} & Sewer Line & & Sewer Statistic & $\begin{array}{l}\text { Unnecessary } \\
\text { data }\end{array}$ \\
\hline & & & Volume & $\begin{array}{l}\text { Unnecessary } \\
\text { data }\end{array}$ \\
\hline & & Sewer Line ID & & \\
\hline & & Fail Reference & & \\
\hline & & Complaint No & & \\
\hline & & Complaint Date & & \\
\hline & & $\begin{array}{l}\text { Status of } \\
\text { Complaint }\end{array}$ & & \\
\hline \multirow[t]{6}{*}{3.} & $\begin{array}{l}\text { PE Verification Report } \\
\text { (PEV) }\end{array}$ & Fail Reference & & \\
\hline & & Asset Number & & \\
\hline & & Design PE & & \\
\hline & & Street Name & & \\
\hline & & Lot Number & & \\
\hline & & PEV Date & & \\
\hline \multirow[t]{3}{*}{4.} & $\begin{array}{l}\text { Planning Approval } \\
\text { (PDC1) }\end{array}$ & Fail Reference & & \\
\hline & & $\begin{array}{l}\text { Developer } \\
\text { Name }\end{array}$ & & \\
\hline & & Project Title & & \\
\hline
\end{tabular}

\section{RESULT AND DISCUSSION}

\section{The Summary of Questionnaire Results}

The result of the interview with the IGIS respondents shows that all of the respondents requested on updating the necessary spatial and attribute data, such as PEV, PDC1, as well as removing unnecessary attribute data from the IGIS. IGIS respondents were selected from the PLS, OMD and CA who are directly involved with this application. The total number of IGIS respondents that was interview is 50 practitioners with 21 questions. After that, this attribute data was analyzed using a content analysis and a questionnaire form has been distributed to the all IGIS 
Muhamad Zuraini Idris, Robiah Suratman, Salfarina Samsuddin

An Improvement of Integrated Geographical Information System in Managing Sewerage Treatment Plant

respondents in getting their feedbacks on the new capabilities of IGIS. The findings shows that, $100 \%$ of the respondents agree with this new improvement of the IGIS and is summarized in Table 2 below.

Table 2: Summary of Questionnaire Result

\begin{tabular}{|c|l|c|c|}
\hline No. & \multicolumn{1}{|c|}{ Description } & Agreed (\%) & $\begin{array}{c}\text { Strongly Agreed } \\
(\%)\end{array}$ \\
\hline 1. & $\begin{array}{l}\text { Planning Purpose } \\
\text { The result of the analysis obtained } \\
\text { to be used in planning works. }\end{array}$ & 88.0 & 12.0 \\
\hline 2. & $\begin{array}{l}\text { Purpose of Study Area Profile } \\
\text { The result of the analysis obtained to } \\
\text { identify the profile of the study area. }\end{array}$ & 95.0 & 5.0 \\
\hline 3. & $\begin{array}{l}\text { Cost Saving Purpose } \\
\text { The result of the analysis obtained to } \\
\text { be used in reducing the company } \\
\text { expenses. }\end{array}$ & 76.0 & 24.0 \\
\hline
\end{tabular}

\section{The New Capabilities of IGIS Application}

This section will discuss the result from the enhanced IGIS after the required spatial data were added and unnecessary attribute data were removed from the IGIS. From the results of the questionnaire, all the IGIS respondents agreed with this new capability of IGIS and they are opined it will help them in daily works, especially in managing the sewerage facilities and to control the increasing number of STP. The new capabilities of the enhanced IGIS are stated as below:

\section{An Analysis for Nearest Location of STP or NPS}

During an interview with the IGIS respondents, they are requesting the spatial data for PDC1, the information of land such as land area, land owner, lot number, title number and others to be added into IGIS. The result shows with this new spatial data, it can easily assist the GIS unit in searching the location of new development areas proposed by the property developers (Henry and Charles, 2015). Now, the IGIS user can also search the location using a lot number, then the result will display the nearest STP or NPS from the proposed development areas. An updated information of PDC1 into IGIS sees can avoid backloading issues because the information provided to the property developers is up to date, and can indirectly avoid the STP or NPS upgraded more than one time due to wrong information given. As what is currently happening due to the delayed captured information in PDC1. With this new enhanced IGIS, it is requested the GIS unit to update a PDC1 information when received the application from the property developer. This new IGIS capabilities is seen to be able to help the EP in giving their advice to the property developer either to upgrade the existing STP with the new design PE or to build a new STP. If one STP is planned to be upgraded, all the PE for PDC1 that is 
PLANNING MALAYSIA

Journal of the Malaysia Institute of Planners (2021)

connected to it need to be captured and it must meet the requirement of land area as stated in Malaysia Sewerage Industries Guideline (MSIG). As a result, through this analysis, it can assist the PLS to control the unnecessary increasing number of STP or NPS.

\section{An Analysis for Nearest Sewer Line Location}

IGIS respondents are requested to add the spatial data for private STP and Individual Septic Tank (IST) into this IGIS. This new spatial data is seen to be very useful to the IWK for property connection program (Mehari, 2009). Using this IGIS, all the updated locations for the private STP and IST will show on the computer desktop. Based on this information, the EP can easily view and propose all potential premises to be connected to the nearest sewer line before it is connected to the Regional Sewerage Treatment Plant (RSTP). Through this property connection program, indirectly it can help the IWK to create another income. The improvement of attribute data for the sewer line information is also expected to help contractors in excavation work that requires information on manhole depth (Mohd Azrai and Lee, 2002)

\section{Planning Analysis for RSTP Proposal}

Another analysis can be performed using this new IGIS, it can help the PLS in doing a proper planning in their proposal to build a new RSTP in the future (Ruchin et.al, 2019). It is because all the spatial data for the PDC1, private STP and IST have been updated in this IGIS. With the new capabilities of 'Google Earth', these two applications can be linked each other. Thus, with the satellite image it can help the EP in getting the clear depiction on the ground. It also can help the EP to select suitable location for the new proposed RSTP and to choose the potential STP or NPS to be rationalized (P. Neeraja and Rajesh, 2017). An updated land information in IGIS will improve the IWK's ability to recognize the land owner in the land acquisition process. Based on the information on land size, IWK also can give an estimation of land acquisition cost to the JPP (P. Neeraja and Rajesh, 2017). The budget for this new RSTP is usually allocated by the federal government through the JPP. Thus, with this effort, the IWK can reduce the increasing number of STP as well as their operation and maintenance cost.

\section{An Analysis for Rationalization Program}

A program called 'Rationalization Program' is one of the initiatives taken by OMD in reducing the cost of operation and maintenance. Under this program, the small and unprofitable STP will be selected to be rationalized and all the incoming flow will connect to the nearest STP or NPS (K. Deepa, et.al, 2012). The selected STP or NPS to cater the incoming flow from the rationalized STP or NPS normally has a bigger design PE and the meaning of unprofitable STP is the operational and maintenance cost bigger than the billing collection. 
Muhamad Zuraini Idris, Robiah Suratman, Salfarina Samsuddin

An Improvement of Integrated Geographical Information System in Managing Sewerage Treatment Plant

\begin{abstract}
An Analysis for the Public Complaint
There are a few attribute data for the sewer line information were added into IGIS, and it is a sewer line ID, complaint number, the date of the complaint, the status of the complaint and others. Currently, the IGIS users in OMD will update all the information related to the sewer line through online based on their day to day works. Normally, OMD has received the complaint from the public about the issues of an overflow, blockage and missing manhole. Using this IGIS, OMD can give a fast response to the complainant after receiving the complaint report from the customer services. Based on the report received, the IGIS users in OMD will assist the team in providing all the related information before going to the site. Previously, the OMD has faced the problem in getting the related information and need an extra time to find the related as-built drawing as well as the trouble in determining the exact on ground location. This new improvement of IGIS is expected to improve the OMD's smooth workflow process in fulfilling their responsibilities. Besides that, the improved IGIS should be able to improve the IWK's image by reducing the number of public complaints with its capabilities that is able to perform analysis on the arising problems public complaints. From the analysis result, OMD can do a proper planning and improve their decision-making, simultaneously avoiding future problems.
\end{abstract}

\title{
An Analysis for the Illegal Discharge
}

An illegal discharge is one of the major issues faced by IWK every year. Based on the site investigation, the premises such as the food court always discharge their sewage to the nearest SPPA (Jiang B., 2007). There are a few cases that IWK has received summons from the Department of Environment (DOE) due to failure of the sampling results on the compliance standard monitor by DOE. Besides that, the IWK also has spent a hundred thousand ringgit to replace the breakdown equipment. With this new IGIS, the spatial data for the PEV were added and the result of PEV will be updated. Thus, with this information, the IWK can easily conduct monitoring and identify which development that has already connected to an existing SPPA (Martin J. Bunch et.al, 2012). Based on the information of PEV, private STP and IST updated in IGIS, it will help the IWK to monitor which development have submitted their PDC1 or already taken over. Through this new capability, it will help the IWK to observe any illegal connections, to take a legal action against the premise owner, and to monitor any new development that has not been recorded into IGIS based on the results from the PEV.

\section{An Analysis for Outstanding Bill}

One of the new spatial data requests form the IGIS respondent during the face-toface interview is to add the information of property buyers into IGIS. This property buyers' information is based on the form called the 'Purchaser List', taken from the 
PLANNING MALAYSIA

Journal of the Malaysia Institute of Planners (2021)

complete documentation submitted by CA to PLS. Then the GIS unit will update the related information such as the owner's name, house number, street name, location name, IC number, contact number and others into IGIS. This IGIS database automatically will link with the system called 'Billing and Revenue Information System (BRAINS)' controlled by CBCD. Thus, with this new capability of IGIS, the CBCD staff can monitor easily the unpaid customers with which location and they also can send a reminder letter to them.

\section{CONCLUSION}

In conclusion, all the respondents agreed that the outcomes of improving the existing IGIS are very useful and beneficial to all parties in IWK. The new capabilities of IGIS such as an analysis for outstanding bill and an analysis for the public complaint, will help the IWK to manage the sewerage system more efficiently. Using these new capabilities, the IWK can improve their work, conduct proper planning in controlling the number of STP every year. The main objective of this improvement of IGIS is intended to ensure that all related information on sewerage is updated regularly and strategically. Thus, IGIS will be able to assist all the related departments in IWK to solve their problems including monitoring unpaid customers. Known as the 'enabling technology', the GIS also can be integrated with various technologies, especially related to the spatial data such as a remote sensing because of its various abilities.

\section{ACKNOWLEDGEMENT}

The authors greatly acknowledge the full support from the Malaysia University of Technology (UTM). Authors sincerely thank all the referees for their suggestions to improve this manuscript.

\section{REFERENCES}

Berita Harian (2012). Caj pembetungan IWK paling rendah. Thursday 10/5/2012 [cited $15 / 4 / 2019]$.

Available from:http://iwk.com.my/cms/upload files/news file 000292.jpg

DeMer. M. (2005). Fundamental of geographic information system. $3^{\text {rd }}$ Ed. John Wiley \& Sons. Pp 233-237.

Henry Abuga and Charles Mundia Ndegwa (2015). "Developing a Sewerage Management System for Kisii Town Using GIS and Remote Sensing". Proceeding of the Sustainable Research and Innovation (SRI) Conference, 6-8 May 2015, ISSN: 20796226.

Indah Water Konsortium Sdn Bhd. Available from: http:www.iwk.com.my

Janhvi Doshi (2002). "An Investigation of Leaky Sewers as a Source of Fecal Contamination in the Storm Water Drainage System in Singapore". Massachusetts Institute of Technology.

Jiang, B. (2007). "Editorial: Some thoughts on geospatial analysis and modelling". Computers, Environment and Urban Systems, Vol. 31, Issue 5, pp. 478-480. 
Muhamad Zuraini Idris, Robiah Suratman, Salfarina Samsuddin

An Improvement of Integrated Geographical Information System in Managing Sewerage Treatment Plant

K. Deepa, M. Krishnaveni (2012). "Suitable Site Selection of Decentralised Treatment Plants Using Multicriteria Approach in GIS". Journal of Geographic Information System (JGIS), Vol.4, 254-260.

Kumpulan Media Karangkraf (2018). Kos rawatan kumbahan meningkat. Monday 22/10/2018 [cited 2/4/2019]. Available from: https://www.karangkarf.com.nasional/kos-rawatan-kumbahan-meningkat-1.895162

Maguire M and Bevan N (2002). User Requirements Analysis: A Review of Supporting Methods. Proceeding of IFIP $17^{\text {th }}$ World Computer Congress, Montreal, Canada, 2530 August 2002, Pp 133-148. Kluwer Academic Publishers.

Malaysian Sewerage Industry Guidelines $3^{\text {rd }}$ Edition, Volume 4, National Water Services Commission (SPAN)

Martin J. Bunch, T. Vasantha Kumaran and R. Joseph (2012). "Using Geographic Information System (GIS) For Spatial Planning and Environmental Management in India: Critical Consideration". International Journal of Applied Science and Technology, Vol.2, No.2, February 2012.

Mehari Goitom Haile (2009). "GIS Based Estimation of Sewer Properties from Urban Surface Information", Institute of Hydrology and Meteorology, Technical University of Dresden.

Mohd Azraai Kassim \& Lee Jen Loong (2002). "A Study on variations in sewerage construction project". Jurnal Teknologi, 37(B) Dis. 2002: 13-26, Fakulti Kejuruteraan Awam, Universiti Teknologi Malaysia.

Mstar (2016, October 17). IWK tutup lebih 500 loji sekitar Lembah Klang. [Cited 2019 April 2]. Available from: https://www.mstar.com.my/niaga/2016/10/17/iwk-tutup-loji

P. Neeraja and Y. Rajesh Kumar (2017). "Site Suitability Analysis for Location of Sewage Treatment Plant". International Journal of Research in Applied Science \& Engineering Technology (IJRASET), ISSN: 2321-9653, Vol.5, Issue XII December 2017.

Ruchin Agrawal, Amitabh Kumar Srivastava and Anjani Kumar Nigam (2019). "GIS and AHP Based Site Suitability for Sewage Treatment Plant in Sultanpur District, India”. International Journal of Innovative Technology and Exploring Engineering (IJITEE), ISSN: 2278-3075, Vol. 8, Issue-6S4.

T. Yue, L.C. Briand and Y. Labiche (2010). A Systematic Review of Transformation Approaches between User Requirement and Analysis Models. Springer. Pp 75-99.

The Malaysian Reserve (2019). Prima government assets ready for listing. Thursday 28/3/2019 [cited 1/4/2019]. Available from: https://themalaysianreserve.com/2019/03/28/prime-government-assets-ready-forlisting/

Utusan Malaysia (2018). Loji kumbahan 5 tahun tidak beroperasi. Tuesday 11/12/2018 [cited 2/4/2019]. Available from: http://www.utusan.com.my/berita/wilayah/kedah/lojikumbahan-5-tahun-tidak-beroperasi-1.802694

Young RR (2001). Effective Requirements Practices. Addison-Wesley Boston.

Received: $19^{\text {th }}$ August 2021. Accepted: $25^{\text {th }}$ November 2021 